\title{
Marx e o Direito do trabalho: a luta de classes, o terreno jurídico e a revolução
}

\author{
Vitor Sartori ${ }^{1}$ \\ https://orcid.org/0000-0001-9570-9968 \\ ${ }^{1}$ Universidade Federal de Minas Gerais, Faculdade de Direito, Departamento de Direito do Trabalho e Introdução ao Estudo do Direito, \\ Belo Horizonte, MG, Brasil
}

\begin{abstract}
Marx e o Direito do trabalho: a luta de classes, o terreno jurídico e a revolução
Resumo: Neste artigo trataremos da relação de Marx com o emergente Direito do trabalho. Pretendemos mostrar que ao mesmo tempo em que Marx considera o terreno jurídico como um palco do conflito classista, ele traz à tona as limitações da esfera jurídica. Com isso, diz Marx ser essencial a luta pela diminuição da jornada de trabalho, bem como a busca pela regulamentação jurídica. No entanto, simultaneamente, enxerga tais lutas, na melhor das hipóteses, como parte da preparação do terreno revolucionário, em que, em verdade, segundo ele, trata-se de suprimir a sociedade capitalista, o Direito e a própria centralidade que a atividade produtiva adquire na vida dos homens da sociedade burguesa. Se Marx diz que a diminuição radical da jornada de trabalho é necessária, trata-se de algo que não seria possível por meio do Direito, mas pela transformação substantiva da produção.
\end{abstract}

Palavras-chave: Marx. Direito do trabalho. Luta de classes.

\section{Marx and Labor Law: The class struggle, the legal arena, and the revolution}

Abstract: This article discusses the relation between Marx and the emerging labor law. The study shows that Marx points out the limitations of the legal arena, at the same time as he considers it as a stage of class struggle. According to Marx, it is crucial to fight for the reduction of the working day, as well as for legal regulation. However, at best he sees such struggles as part of the preparation of the revolutionary terrain in order to suppress the capitalist society, the law, and the centrality of the productive activity in the life of the human in the bourgeois society. Therefore, when Marx advocates for a radical reduction of the working day, he is not referring to a struggle in the legal arena, but a substantive transformation of production.

Keywords: Marx. Labor law. Class struggle.

Recebido em 01.10.2018. Aprovado em 20.11.2018. Revisado em 17.04.2019.

(C) O(s) Autor(es). 2019 Acesso Aberto Esta obra está licenciada sob os termos da Licença Creative Commons Atribuição-NãoComercial 4.0 Internacional (https://creativecommons.org/licenses/by-nc/4.0/deed.pt_BR), que permite copiar, distribuir e reproduzir em qualquer meio, bem como adaptar, transformar e criar a partir deste material, desde que para fins não comerciais e que você forneça o devido crédito aos autores e a fonte, insira um link para a Licença Creative Commons e indique se mudanças foram feitas. 
Jamais o escondemos. Nosso terreno não é o terreno do direito, é o terreno revolucionário. (MARX, 2010, p. 318)

Toda classe em luta precisa [...] formular suas reivindicações em um programa, sob a forma de reivindicações jurídicas. (ENGELS; KAUTSKY, 2012, p. 47)

\section{Introdução}

Estudar a posição de Marx nem sempre é simples. Isto se mostra bastante claro ao se perceber as inúmeras posições que, partindo do autor de $O$ Capital, manifestam-se sobre temas polêmicos. Em meio a avaliações diferentes sobre o trabalho na obra marxiana - como aquela que defende que há centralidade do trabalho na análise do autor (ANTUNES, 2008) ou aquela que defende que Marx, em verdade, é um crítico do trabalho (POSTONE, 2014) - procuraremos trazer à tona o modo pelo qual, em Marx (2013), tem-se uma abordagem bastante rica acerca da emergente regulamentação do trabalho fabril. Acreditamos que, em meio a esta temática, o autor alemão explicita um caráter dúplice do trabalho e da relação deste último com a crítica da sociedade capitalista. Assim, analisar a obra do próprio autor de $O$ Capital pode ser bastante proveitoso.

Ou seja, aqui, não tomaremos o caminho convencional ao analisar a questão do trabalho em Marx: a saber, tratar da relação entre trabalho concreto, trabalho abstrato, exteriorização da vida (Lebensäusserung), alienação (Entäusserung), venda (Veräusserung) e estranhamento (Entfremdung). Em meio ao tratamento marxiano da oposição entre o capitalista coletivo e o trabalhador coletivo - ou seja, entre as personificações (Träger) do capital e do trabalho - procuraremos mostrar a dubiedade existente, de acordo com o texto marxiano, quando se trata da relação entre o trabalho, a luta de classes e as reivindicações e conquistas jurídicas.

A partir da análise imanente ${ }^{1}$ do texto do próprio Marx (2013), procuraremos explicitar a relação existente entre a categoria trabalho, a luta de classes e o Direito. Com isso, ter-se-á em conta o modo pelo qual, ao mesmo tempo em que a posição (Standpunkt) do trabalho não é resolutiva, em Marx (2012b), ao opor-se ao capital, ela pode (embora isto ocorra de modo necessário) abrir espaço para o questionamento substancial da sociabilidade eivada pela reprodução do capitalismo ${ }^{2}$. Intentamos apreender com cuidado este movimento contraditório - presente na obra do autor de $O$ Capital, mas também na própria realidade. E, para tanto, por mais que o estudo da obra marxiana seja controverso em meio ao próprio marxismo, acreditamos, deve-se voltar ao próprio texto de Marx.

Isto se dá, em grande parte, devido aos meandros - que analisaremos neste pequeno texto - que estão envolvidos no tratamento marxiano da relação entre a perspectiva do trabalho e o Direito. Ou seja, analisamos a obra de Marx (2012b, 2013), primeiramente, para iluminar aspectos essenciais à compreensão de nossa época, em que os dilemas do mundo do trabalho são muitos. Além de tal interesse, claro, tem-se a análise de um assunto controverso na obra de um autor clássico.

\section{O avanço do capital diante do trabalho em meio ao modo de produção capitalista emergente: vida cotidiana e classe trabalhadora}

Para Marx (2013), a dinâmica do modo de produção capitalista parece ter por trás de si uma espécie de sujeito automático como aquele que preside o processo de reprodução social. Diz Marx (1996a, p. 273-274) sobre o valor que "ele passa continuamente de uma forma para outra, sem perder-se nesse movimento, e assim se transforma num sujeito automático". A questão, porém, passa por uma espécie de mistificação, que faz parte da própria constituição objetiva da sociabilidade capitalista. Ela está relacionada, de modo mediado, ao caráter fetichista da mercadoria e, por extensão, do capital já que "[...] o movimento, pelo qual ele adiciona mais-valia [Merwert], é seu próprio movimento, sua valorização, portanto autovalorização. Ele recebeu a qualidade oculta de gerar valor porque ele é valor. Ele pare filhotes vivos ou ao menos põe ovos de ouro". (MARX, 1996a, p. 274). Ou seja, em meio ao processo de valorização do capital, tem-se uma inversão gritante, objetiva e presente na própria realidade efetiva: o valor parece se autovalorizar e parece ser uma espécie de sujeito automático. E, na imediatidade da realidade efetiva, isso, até certo ponto, é verdadeiro. Ele põe ovos de ouro e tem qualidades ocultas, sendo valor que gera valor.

No entanto, isto só pode ocorrer porque seu movimento é dependente da extração de mais-valor (Merwert) e, portanto, do trabalho. A reprodução do capital, assim, parece ser automática e parece ser independente de 
quaisquer determinações alheias ao capital. Aponta Marx (2017), no Livro III de O Capital, algo importante sobre o tema que mencionamos: a aparência é parte movente e movida da própria realidade, de modo que tal mistificação é objetiva, mas continua sendo o que é, uma inversão. Isto se dá até mesmo porque "[...] toda a ciência seria supérflua se a forma de manifestação e a essência das coisas coincidissem imediatamente [...]" (MARX, 1986b, p. 271). Diz também o autor (MARX, 1986a, p. 160), neste sentido, que aquilo que se mostra na superfície da sociedade capitalista, "[...] difere consideravelmente [de sua essência, de sua figura medular], sendo de fato o inverso, o oposto, de sua figura medular interna, essencial mas oculta, e do conceito que lhe corresponde". Ou seja, o capital aparece como uma potência demiúrgica somente ao passo que é dependente do trabalho. Na imediatidade, ele é autônomo e se transforma em um sujeito automático; no entanto, isso é tudo que ele não pode ser. $\mathrm{O}$ trabalho é subsumido ao capital somente à medida que o último é dependente do primeiro. Como diz Marx (1996a, p. 347): “o capital é trabalho morto, que apenas se reanima, à maneira dos vampiros, chupando trabalho vivo e que vive tanto mais quanto mais trabalho vivo chupa". Ou seja, o sujeito automático é permeado pela compulsão de gerar valor, certamente, mas seu automatismo é bastante peculiar e envolve o processo social de normalização das “[...] exigências daquele modo de produção como leis naturais evidentes". (MARX, 1996b, p. 358).

O capital, em sua forma de aparição imediata, “[...] difere consideravelmente [...] do conceito que lhe corresponde". (MARX, 1996a, p. 160). Ele parece autônomo à medida que não pode ser. E isto é verdade mesmo que "na realidade (isto é, no mundo fenomênico), o que se vê é o inverso". (MARX, 2017, p. 72)33.

É essencial destacar tal aspecto porque o processo de subsunção do trabalho ao capital é aquele em que a classe trabalhadora se coloca cotidianamente em meio à relação-capital. E, neste sentido, deve-se destacar que esta relação "não pode ser outra coisa que o processo de separação de trabalhador da propriedade das condições de trabalho”, no que continua Marx (1996b, p. 340), “[...] um processo que transforma, por um lado, os meios sociais de subsistência e de produção em capital, por outro, os produtores diretos em trabalhadores assalariados". Ou seja, a relação-capital, que coloca o trabalho como subordinado ao capital supõe "a assim chamada acumulação primitiva [...]" (MARX, 1996b, p. 340). Nela, a violência estatal e extraeconômica é necessária para que se consiga um "[...] grau normal de dependência" (MARX, 2013, p. 984) do trabalho diante do capital. Ou seja, por mais que as determinações econômicas sejam o decisivo na conformação da realidade efetiva, há mediações econômicas e extraeconômicas que colocam a imediatidade como tal. Diz Marx (1996b, p. 358):

Não basta que as condições de trabalho apareçam num polo como capital e no outro polo, pessoas que nada têm para vender a não ser sua força de trabalho. Não basta também forçarem-nas a se venderem voluntariamente. Na evolução da produção capitalista, desenvolve-se uma classe de trabalhadores que, por educação, tradição, costume, reconhece as exigências daquele modo de produção como leis naturais evidentes.

Longe de haver, real e efetivamente, um sujeito automático, tem-se a conformação da normalidade do modo de produção capitalista - ou seja, sua imediatidade - sendo produzida, em um primeiro momento, mediante a atuação estatal e por meio da educação, tradição e costume. Atuando diante das relações econômicas objetivas, potências extraeconômicas liberam os entraves de relações econômicas de produção as quais, a partir de então, são tomadas como suposto da atividade cotidiana e, somente então, aparecem na imediatidade em meio à autovalorização do valor. Tem-se a aparência de um sujeito automático, do valor que gera valor no cotidiano capitalista; e, assim, aparecem como supostas na imediatidade da realidade efetiva em determinada formação social. A aparência relativa à autonomia do capital depende de determinações contraditórias, cuja estruturação diuturna depende da manutenção da subordinação do trabalho ao capital. Trata-se do processo que passa pela "assim chamada acumulação primitiva" (MARX, 1996b, p. 340) e que precisa ser resguardado diuturnamente para que o capital mantenha sua forma de aparição autonomizada na imediatidade.

Ou seja, mesmo depois de as condições de trabalho aparecerem como capital e depois de os homens aparecerem como "[...] pessoas que nada têm a vender a não ser sua força de trabalho" (MARX, 1996b, p. 358), não se tem conformada natural e automaticamente a relação-capital. Para que essa relação apareça colocada sobre seus próprios pés, é necessário o desenvolvimento de uma classe de trabalhadores que, até certo ponto, reconhece as exigências do modo de produção capitalista como "[...] leis naturais evidentes". (MARX, 1996b, p. 358). Por conseguinte, há de se notar que o processo pelo qual a relação-capital torna-se algo cotidiano não é nada simples e envolve diversas mediações. Elas passam pela educação, pela tradição e pelo costume. Mas, em verdade, demandam grande medida de violência estatal; todos estes, por sua vez, atuam diante de determinações econômicas objetivas, como não poderia deixar de ser. Por meio das últimas, com a educação da classe trabalhadora, pode-se, inclusive, usar de casas de trabalho forçado e do cárcere (MELOSSI; PAVARINI, 2006; RUSCHE; KIRCHHEIMER, 2004). Trata-se do complexo processo median- 
te o qual as pessoas que compõem a classe trabalhadora são forçadas a venderem voluntariamente a força de trabalho. E tal unidade imediata entre coerção e vontade é parte essencial da vida cotidiana da classe trabalhadora na sociedade capitalista. Em $O$ Capital, diz-se algo de grande importância para a compreensão do processo em que a relação-capital se põe e impõe por leis naturais e evidentes:

\begin{abstract}
A organização do processo capitalista de produção desenvolvido quebra toda a resistência; a constante geração de uma superpopulação relativa mantém a lei da oferta e da demanda de trabalho, e, portanto, o salário, nos trilhos convenientes às necessidades de valorização do capital; a coerção muda exercida pelas relações econômicas sela o domínio do capitalista sobre o trabalhador. A violência extraeconômica, direta, continua, é claro, a ser empregada, mas apenas excepcionalmente. Para o curso usual das coisas, é possível confiar o trabalhador às "leis naturais da produção", isto é, à dependência em que ele mesmo se encontra em relação ao capital, dependência que tem origem nas próprias condições de produção e que por elas é garantida e perpetuada. Diferente era a situação durante a gênese histórica da produção capitalista. A burguesia emergente requer e usa a força do Estado para "regular" o salário, isto é, para comprimi-lo dentro dos limites favoráveis à produção de mais-valor, a fim de prolongar a jornada de trabalho e manter o próprio trabalhador num grau normal de dependência. Esse é um momento essencial da assim chamada acumulação primitiva. (MARX, 2013, p. 983-984).
\end{abstract}

Também por meio da educação, tradição e costume, quebra-se a resistência da classe trabalhadora. A base real deste processo é o desenvolvimento das forças produtivas, bem como sua contradição com as relações de produção de determinada época; "a organização do processo capitalista de produção [...]", bem como a "[...] superpopulação relativa [...]" (MARX, 2013, p. 983), tem, porém, o papel decisivo. Com isto, os pais do moderno proletariado acabam por adequar-se ao processo capitalista de produção a duras penas e somente porque, diz Marx (1996b, p. 358) sobre as pessoas: “[...] forçarem-nas a se venderem voluntariamente”. Tal unidade entre vontade e coerção tem uma relação íntima com "[...] o processo de separação entre o trabalhador e a propriedade das condições de realização de seu trabalho [...]" (MARX, 2013, p. 961); no entanto, isto diz respeito também a mecanismos econômicos (organização da produção e superpopulação relativa) e extraeconômicos (casas de trabalho, cárcere, legislação sanguinária) de coerção. Tem-se como exemplos a existência do famoso exército industrial de reserva e o uso da legislação penal. O processo de normalização da sociabilidade capitalista é aquele em que se forma uma classe de trabalhadores que "[...] reconhece as exigências daquele modo de produção como leis naturais evidentes" (MARX, 1996b, p. 358), como já destacamos. No entanto, há de se apontar que se trata do processo em que "a violência extraeconômica, direta, continua, é claro, a ser empregada, mas apenas excepcionalmente". (MARX, 2013, p. 983-984). Assim, para que a classe trabalhadora se coloque como subsumida ao domínio burguês, é necessário um processo longo. Somente depois que a assim chamada acumulação primitiva completa-se em seus delineamentos essenciais é que a jornada normal de trabalho pôde ser estabelecida. Ela mesma é decorrente do contraditório processo que se dá no terreno político da luta de classes e que tem por base as determinações econômicas do desenvolvimento do modo de produção capitalista. Não se pode desconsiderar nenhum desses polos em uma análise cuidadosa.

Regular os salários - assunto essencial quando se tem em conta o Direito do trabalho ${ }^{4}$ - requer uma medida estabelecida socialmente. E esta última é o resultado dos antagonismos classistas colocados em meio ao desenvolvimento das contradições do sistema capitalista de produção. Dizer isso, porém, não basta. É preciso que se diga que há diversos momentos desta regulação e, portanto, de luta. O momento inicial é aquele da "[...] assim chamada acumulação primitiva", em que a ofensiva da burguesia em formação delineia-se ao passo que "a burguesia emergente requer e usa a força do Estado para 'regular' o salário [...]" (MARX, 2013, p. 984). Neste momento, por meio de leis sanguinárias, e pelo uso explícito da violência estatal, busca-se ampliar o mais-valor absoluto "[...] dentro dos limites favoráveis à produção do mais-valor [...]"s (MARX, 2013, p. 984). Prolonga-se, assim, a jornada de trabalho da classe trabalhadora. E somente assim, gera-se um “[...] grau normal de dependência" (MARX, 2013, p. 984) desta classe em relação à burguesia. Trata-se do processo pelo qual "na evolução da produção capitalista, desenvolve-se uma classe de trabalhadores que, por educação, tradição, costume, reconhece as exigências daquele modo de produção como leis naturais evidentes". (MARX, 1996b, p. 358).

O primeiro momento da subsunção do trabalho ao capital, portanto, coloca a relação-capital sob os próprios pés por meio de uma ofensiva da burguesa em formação. Esta ofensiva é a base real da conformação da vida cotidiana da classe trabalhadora que foi forçada a voluntariamente colocar-se em meio ao automatismo da relação-capital, aceitando o modo de produção capitalista como uma espécie de segunda natureza. Tem-se, neste momento, a extração de mais-valor absoluto como base do processo social em que se dá a luta de classes. No entanto, nem sempre se está sobre este solo. 


\section{Lutas de classe e resistência ao cotidiano da sociabilidade capitalista}

Pode-se ter um processo produtivo em que a extração de mais-valor já tem por essencial, não tanto o mais-valor absoluto, mas o relativo. O processo da "assim chamada acumulação primitiva [...]" (MARX, 1996b, p. 340) coloca o capital sobre os próprios pés ao mesmo tempo em que, em seu desenvolvimento meandrado, traz o domínio capitalista como parte do cotidiano da classe trabalhadora. Em um primeiro momento, trata-se de lutas colocadas diante da extração de mais-valor absoluto para, depois, em meio ao crescimento da luta dos próprios trabalhadores, ter-se o mais-valor relativo como foco. Este processo econômico traz consigo uma certa imediatidade. O cotidiano, a partir do momento em que a relação-capital se coloca sobre os próprios pés, é marcado por uma situação em que as pessoas aparecem como meras funções no processo produtivo do capital sem nunca poderem ser reduzidas a isso (MARX, 1986a). Marx (1996a, p. 391) diz sobre a relação-capital no século XIX:

Logo que a classe trabalhadora, atordoada pelo barulho da produção, recobrou de algum modo seus sentidos, começou sua resistência, primeiro na terra natal da grande indústria, na Inglaterra. Contudo, durante três decênios, as concessões conquistadas por ela permaneceram puramente nominais. O Parlamento promulgou, de 1802 até 1833, 5 leis sobre o trabalho, mas foi tão astuto que não voltou um tostão sequer para sua aplicação compulsória, para os funcionários necessários etc. Essas leis permaneceram letra morta.

O momento da "assim chamada acumulação primitiva [...]” (MARX, 1996b, p. 340) é aquele em que se traz contraditoriamente o "[...] grau normal de dependência" (MARX, 2013, p. 984) do trabalho diante do capital; também é aquele momento em que, mediante uma ofensiva da burguesia, são alargadas as jornadas de trabalho (e, portanto, o mais-valor absoluto), regulando - com o auxílio do Direito - a duração normal do dia de trabalho. Depois deste momento (o qual parece vir como uma espécie de ataque que atordoa a classe trabalhadora), começa uma resistência aos imperativos do capital. E, segundo Marx (2013), isto se dá com conquistas legais decorrentes das lutas dos trabalhadores. No que vale destacar: também neste ponto, a dicção marxiana expressa a contradição deste processo. O autor alemão (MARX, 1996a, p. 391) fala de "[...] concessões conquistadas [...]". Tal qual antes a unidade entre coerção e vontade aparecia ao se tratar da venda da mercadoria força de trabalho, aqui tem-se uma unidade - característica da resistência - entre o reconhecimento do modo de produção capitalista como uma base natural e a crítica aos resultados deste. Trata-se de uma classe de trabalhadores que "[...] reconhece as exigências daquele modo de produção como leis naturais evidentes". (MARX, 1996b, p. 358). No entanto, não se tem somente isto: a organização da classe trabalhadora se dá, também, mediante estas reivindicações que se colocam no terreno do Direito; e, deste modo, tem-se também parte de um processo em que, em meio ao desenvolvimento do próprio modo de produção capitalista, é possível a esta classe social perceber os limites tanto do próprio sistema capitalista de produção quanto da aposta na regulação jurídica.

Neste momento, tem-se, em O Capital, algo muito próximo ao que destacaram Engels e Kautsky (2012, p. 19): "as primeiras formações partidárias proletárias, assim como seus representantes teóricos, mantiveramse estritamente no jurídico "terreno do direito", embora construíssem para si um terreno do direito diferente daquele da burguesia". As leis protetivas contra os avanços do capital - caso se queira trazer uma dicção diferente à legislação trabalhista - trazem uma resistência considerável ao modo de produção capitalista. No entanto, também ao permanecerem no terreno do Direito, deve-se apontar: há certa unidade entre a crítica à produção capitalista e a aceitação dos supostos reais desta. Neste ponto, tem-se a funcionalidade das lutas da classe trabalhadora diante da base econômica que pode ser liberada com tal papel ativo da esfera jurídica: a passagem do mais-valor absoluto ao relativo. Tal regulamentação jurídica é necessária, também, ao próprio modo de produção capitalista no momento tratado por Marx em $O$ capital.

É interessante, porém, considerar que tais concessões conquistadas teriam ficado somente no papel em um primeiro momento. Permanecem puramente nominais e letra morta já que "o parlamento [...] não voltou um tostão sequer para a sua aplicação compulsória [...]” (MARX, 1996a, p. 391). Ou seja, Marx (1996a) é muito claro quanto às restrições destas conquistas da classe trabalhadora em meio à legislação fabril. Antes de meados de século XIX, a classe trabalhadora colocava-se no "[...] jurídico 'terreno do Direito' [...]" (ENGELS; KAUTSKY, 2012, p. 19) e suas conquistas apareciam como concessões. Tal unidade dúbia decorre do caráter reativo da luta de classes da época em que "o capital celebrava suas orgias". (MARX, 1996a, p. 391). O modo pelo qual tais orgias eram reguladas, inclusive, trouxe consigo um papel bastante ativo do Direito. A jornada normal de trabalho, portanto, não tinha como parâmetro a natureza humana (MÁRKUS, 2015) ou as necessidades e capacidades dos trabalhadores (MARX, 2012b). Em verdade, tem-se os imperati- 
vos do capital se impondo e uma tentativa de resistência a estes imperativos. Aquilo que poderíamos chamar de Direito do trabalho emergente, portanto, expressa uma resistência diante das orgias do capital; no entanto, tem por base econômica o processo em que, no próprio capitalismo, passa-se da extração de mais-valor absoluto ao mais-valor relativo.

Deste modo, o reconhecimento da medida a ser trazida na regulamentação do trabalho da grande indústria liga-se intimamente a esta luta e ao modo pelo qual, por meio do Direito, tem-se - para que se use a expressão de Marx de a Miséria da Filosofia (2004, p. 84) - "[...] o reconhecimento oficial do fato" (SARTORI, 2010). As orgias mencionadas por Marx (1996a) dizem respeito ao processo de extração de mais valorabsoluto, ao passo que, com as lutas dos trabalhadores, o capital foi forçado a trazer o mais-valor relativo à tona de modo mais incisivo. Veja-se o que diz Marx (1996a, p. 391) sobre este primeiro momento, em que "o capital celebrava suas orgias":

Depois que o capital precisou de séculos para prolongar a jornada de trabalho até seu limite máximo normal e para ultrapassá-lo até os limites do dia natural de 12 horas, ocorreu então, a partir do nascimento da grande indústria no último terço do século XVIII, um assalto desmedido e violento como uma avalancha. Toda barreira interposta pela moral e pela natureza, pela idade ou pelo sexo, pelo dia e pela noite foi destruída. Os próprios conceitos de dia e noite, rusticamente simples nos velhos estatutos, confundiram-se tanto que um juiz inglês, ainda em 1860, teve de empregar argúcia verdadeiramente talmúdica, para esclarecer “juridicamente" o que seja dia e o que seja noite. O capital celebrava suas orgias.

Toda a barreira natural e moral ao prolongamento da jornada de trabalho teria sido destruída. Tal seria a obra, de um lado, da própria "[...] organização do processo capitalista de produção [...]" (MARX, 2013, p. 983), doutro, da educação, do costume, da tradição e da violência estatal. Esta última, não raro, foi trazida à tona com leis terroristas, com casas de trabalho forçado e com o cárcere. A fase ascensional da burguesia corresponde, pois, não só ao ápice de um ímpeto democrático e cidadão, mas aos séculos em que a jornada de trabalho é colocada em seu máximo normal: trata-se de um processo que tem por base real o estabelecimento do assalariamento e da relação-capital mesma, buscando-se elevar ao máximo o mais valor-absoluto e, depois, o mais-valor relativo. E, claro, tal normalidade da jornada de trabalho não passaria tanto pela consideração humanista da idade, do sexo ou das condições noturnas de trabalho; antes, tem-se a imposição - sempre mediante a venda voluntária da força de trabalho - dos interesses burgueses, relacionados à consolidação e à acumulação do capital em meio à vida dos homens. Ou seja, o estabelecimento de uma jornada normal de trabalho, bem como de um grau normal de dependência, tem como pano de fundo a ofensiva do capital diante do trabalho. E, neste ponto, há de se destacar que o papel ativo do Direito neste processo é bastante importante: diante do afastamento das barreiras naturais a que estava submetida a produção, busca-se estabelecer barreiras sociais, no caso, jurídicas. E isto se dá mesmo que o estabelecimento de tal regulamentação buscasse, de início, não a limitação da jornada de trabalho, mas sua expansão orgiástica. Só em um segundo momento é que a regulamentação fabril é acompanhada pelo mais-valor relativo e, portanto, por uma relação com a mercadoria força de trabalho menos imediatamente brutal; durante séculos, a tal regulamentação veio justamente a reconhecer as orgias do capital, aumentando a brutalidade da extração do mais-valor.

Em meio a isto, a “[...] argúcia verdadeiramente talmúdica [...]” (MARX, 1996a, p. 391) dos magistrados parecia ser a única capaz de - diante dos imperativos de expansão da jornada do trabalho (relacionados à extração de mais-valor absoluto) - estabelecer o que seria propriamente o dia e o que seria a noite. O papel do elemento jurídico diante de tal cenário é bastante proeminente, portanto.

Mediante o Direito, aquilo que ao trabalhador parecia bastante intuitivo (o conceito de dia e de noite) foi tratado de modo técnico-jurídico em meio ao reconhecimento estatal da ampliação violenta das jornadas de trabalho. Mesmo o estabelecimento do período noturno aparece como algo somente compreensível em meio à regulamentação jurídica. Porém, por mais que o Direito pareça ser o essencial, Marx (1996a, p. 349) diz que a questão coloca-se em outro campo:

Vê-se que: abstraindo limites extremamente elásticos, da natureza do próprio intercâmbio de mercadorias não resulta nenhum limite à jornada de trabalho, portanto, nenhuma limitação ao mais-trabalho. O capitalista afirma seu direito como comprador, quando procura prolongar o mais possível a jornada de trabalho e transformar onde for possível uma jornada de trabalho em duas. Por outro lado, a natureza específica da mercadoria vendida implica um limite de seu consumo pelo comprador, e o trabalhador afirma seu direito como vendedor quando quer limitar a jornada de trabalho a determinada grandeza normal. Ocorre aqui, portanto, uma antinomia, direito contra direito, ambos apoiados na lei do intercâmbio de mercadorias. Entre direitos iguais decide a força. E assim a regulamentação da jornada de trabalho apresenta-se na história da 
produção capitalista como uma luta ao redor dos limites da jornada de trabalho - uma luta entre o capitalista coletivo, isto é, a classe dos capitalistas, e o trabalhador coletivo, ou a classe trabalhadora.

Ao se tratar da regulamentação da mercadoria força de trabalho, o terreno em que a questão efetivamente se coloca é aquele da circulação das mercadorias. De um lado, o capitalista coletivo - possuidor dos meios de produção - doutro, o trabalhador coletivo. O conflito entre a classe dos capitalistas e dos trabalhadores, no que toca a regulamentação da jornada de trabalho, claro, pressupõe a própria relação-capital e, portanto, a circulação mercantil. O direito do capitalista, como direito do comprador, aparece justamente ao passo que ele procura usar o máximo possível da mercadoria força de trabalho; no limite, ele tenta - por meio de dois turnos, de horas-extras e de outros artifícios - "[...] transformar onde for possível uma jornada [...] em duas". (MARX, 1996a, p. 349). Doutro lado, o trabalhador procura uma jornada normal, a qual deveria obedecer justamente a especificidades limitadas “[...] pela moral e pela natureza, pela idade ou pelo sexo, pelo dia e pela noite [...]" (MARX, 1996a, p. 391). Ou seja, em meio à circulação mercantil, de um lado, busca-se a otimização do uso da mercadoria força de trabalho, doutro, a busca por limites, que procurariam evitar o abuso diante da natureza desta mercadoria.

A regulamentação da jornada de trabalho, portanto, gira em torno de diferentes modos de lidar com as mercadorias, no caso, principalmente, a força de trabalho. A questão é importante a nosso tema: ela deixa clara a natureza dúbia das barreiras jurídicas: ao mesmo tempo em que se trata de uma conquista da classe trabalhadora, trata-se de uma resistência somente diante de um modo específico mediante o qual se coloca a relação-capital; ou seja, não se tem tanto uma crítica à relação-capital, mas às consequências do domínio desta. Ao se ter em disputa - no terreno do Direito - o modo de lidar com a mercadoria força de trabalho, esta última é naturalizada. E mais, ao que parece o emergente Direito do trabalho (vale lembrar que Marx não usa a expressão) coloca-se muito mais como uma resistência diante da extração do mais-valor absoluto que do relativo.

Outra questão importante decorre desta: já que o intercâmbio de mercadorias não traz qualquer limitação à jornada de trabalho (antes, em verdade, tem-se o oposto), avança-se diante de limitações naturais à mesma. A regulamentação da duração da jornada de trabalho passa a ser socialmente posta. Isto se dá, porém, sob os auspícios da relação-capital. Ou seja, no intercâmbio mercantil, há uma tentativa - por parte da classe capitalista - de explorar os limites extremamente elásticos da jornada de trabalho, trazendo-a a um patamar de exploração bastante elevado. Por outro lado, diante de tal fenômeno, a classe trabalhadora opõe resistência de um modo peculiar: de imediato, no terreno legal, ao invés de buscar estabelecer socialmente a jornada de trabalho limitando-a ao mínimo socialmente necessário (o que implicaria na modificação substantiva do modo social de produção), busca-se reestabelecer barreiras condizentes com a natureza da mercadoria força de trabalho. Ou seja, a luta pela diminuição da jornada de trabalho, sob o modo de produção capitalista, é uma luta entre classes sociais que buscam modos distintos, e antagônicos, de lidar com as mercadorias. O direito de o comprador colocar-se contra o direito do vendedor, tendo-se uma antinomia. E, de acordo com Marx (2013), tal antinomia que aparece no terreno do Direito, é resolvida, ao fim, por meio da força. E, claro, a base de tal processo não poderia deixar de ser o desenvolvimento do modo de produção capitalista, em que, conjuntamente com a possibilidade de diminuição da jornada de trabalho, vem o desenvolvimento da extração de mais-valor relativo, bem como da produtividade do trabalho. As lutas que se colocam no campo jurídico - mesmo que não se reduzam a ele - explicitam o papel ativo do Direito e, ao mesmo tempo destacam as limitações deste.

A luta de classes, mesmo que passe pelo terreno jurídico, coloca-se para além dele. A força (que se conforma como uma sombra diante do Direito) acaba sendo decisiva (SARTORI, 2010). As lutas travadas buscando uma melhor regulamentação jurídica do trabalho são, assim, bastante limitadas por este lado. Ao se ter direito contra direito, a questão decisiva não é hermenêutica: como apontou Marx (1996a, p. 349), “ocorre aqui, portanto, uma antinomia, direito contra direito, ambos apoiados na lei do intercâmbio de mercadorias. Entre direitos iguais decide a força". Trata-se de uma oposição apoiada na lei de intercâmbio de mercadorias e, assim, ela supõe a relação-capital. $\mathrm{O}$ antagonismo entre burguesia e proletariado, em meio à resistência que se coloca corporificada na regulamentação da atividade fabril (que, hoje, poderíamos chamar de Direito do trabalho), traz uma tensão bastante grande com as consequências do modo de produção capitalista. Ao mesmo tempo, deixa-se claro que o terreno do Direito é aquele em que tal produção é suposta.

A questão, porém, não é simples. Tem-se, segundo Marx (1996a, p. 411), uma verdadeira “[...] guerra civil [...]" entre o trabalhador coletivo e o capitalista coletivo. Mesmo que se trate de um terreno em que o sistema capitalista de produção aparece como suposto, trata-se de uma visceral luta de classes:

A história da regulamentação da jornada de trabalho em alguns modos de produção e a luta que ainda prossegue em outros por essa regulamentação demonstram palpavelmente que o trabalhador individual, o trabalhador como "livre" vendedor de sua força de trabalho, a certo nível de amadurecimento da produção 
capitalista encontra-se incapaz de resistir. A criação de uma jornada normal de trabalho é, por isso, o produto de uma guerra civil de longa duração, mais ou menos oculta entre a classe capitalista e a classe trabalhadora. Como a luta foi inaugurada no âmbito da indústria mais moderna, travou-se primeiro na terra natal dessa indústria, na Inglaterra. (MARX, 1996a, p. 411).

A luta pela diminuição da jornada de trabalho coloca-se como uma luta pela regulamentação jurídica desta. Nesta, o trabalhador entra como trabalhador livre ${ }^{6}$, ou seja, como mero possuidor da mercadoria força de trabalho; como tal, diz Marx (1996a), ele é incapaz de resistir ao processo de imposição da produção capitalista. Para que haja resistência, é necessário que os trabalhadores se juntem e se percebam como classe social, antagônica à classe dos capitalistas. A guerra civil que menciona Marx (1996a), portanto, por mais que passe pelo terreno do Direito, ultrapassa em muito este e, se necessário por meio da força, remete à luta de classes. Esta última é colocada politicamente e não somente buscando o reconhecimento jurídico de demandas que giram em torno do melhor modo de lidar com a mercadoria força de trabalho. Sejamos claros: de acordo com o autor de $O$ Capital, o terreno do Direito é essencial para que haja resistência dos trabalhadores diante dos direitos do capital. Diz o autor (MARX, 1996a, p. 405), porém: "e igual exploração da força de trabalho é o primeiro direito humano do capital". Mesmo ao se tratar de direitos humanos, e de sua intersecção com a regulamentação fabril - relacionada por nós ao emergente Direito do trabalho - os limites desta resistência são visíveis ${ }^{7}$. Ao se tratar de uma luta que se atenha ao jurídico, a guerra está perdida. No entanto, os meandros da questão, relacionados à luta dos trabalhadores, explicitam-se ao passo que não é necessário que tal luta seja somente uma luta por direitos. A luta de classes pode ter em conta que "entre direitos iguais decide a força" (MARX, 1996a, p. 349), colocando-se no terreno revolucionário. Ou seja, segundo Marx (2013), mesmo diante das limitações das conquistas jurídicas, o processo mediante o qual estas são trazidas à tona pode (mesmo que isso não se dê automaticamente) trazer um ganho na compreensão dos mecanismos de exploração capitalista. A isto está associada a consciência de classe ${ }^{8}$.

\section{Da resistência à consciência de classe: Direito e política em meio à luta da classe trabalhadora}

Marx (2010, p. 318) é explícito ao tratar do caso alemão em 18489: “jamais o escondemos. Nosso terreno não é o terreno do direito, é o terreno revolucionário. O governo agora acaba de abandonar, por sua vez, a hipocrisia do terreno do direito. Colocou-se sobre o terreno revolucionário, pois também o terreno contrarrevolucionário é revolucionário". Disso surgem questões importantes: primeiramente, o terreno em que Marx se coloca é aquele da revolução. Em segundo lugar: mesmo o terreno da luta burguesa - depois que esta deixa de lado a hipocrisia e mostra sua verdadeira face - pode ser o terreno revolucionário, já que a contrarrevolução e a revolução estão no mesmo terreno. Ou seja, em momentos decisivos, o proletariado e a burguesia colocam-se para além do terreno do Direito e isto somente explicita o real fundamento da sociabilidade do capital. Para Marx (2012b), a questão decisiva, portanto, não é e nem pode ser jurídica.

A questão, porém, é mais complexa: o preparo para o terreno da revolução passa pela luta de classes e esta última, não raro, remete a lutas por direitos. Assim, há de se perceber como que, segundo Marx (2013), em meio ao próprio processo de trabalho em que o trabalhador aparece como um portador de uma mercadoria, pode ser possível ir além desta atomização, inerente à sociedade burguesa. Ou seja, segundo Marx (2012b, 2013), da resistência mesma - e de seu caráter dúbio - é possível um salto qualitativo, que leva a classe trabalhadora do terreno do Direito aos meandros da política ${ }^{10}$.

É preciso reconhecer que nosso trabalhador sai do processo de produção diferente do que nele entrou. No mercado ele, como possuidor da mercadoria "força de trabalho", se defrontou com outros possuidores de mercadorias, possuidor de mercadoria diante de possuidores de mercadorias. $\mathrm{O}$ contrato pelo qual ele vendeu sua força de trabalho ao capitalista comprovou, por assim dizer, preto no branco, que ele dispõe livremente de si mesmo. Depois de concluído o negócio, descobre-se que ele não era "nenhum agente livre", de que o tempo de que dispõe para vender sua força de trabalho é o tempo em que é forçado a vendê-la, de que, em verdade, seu explorador não o deixa, "enquanto houver ainda um músculo, um tendão, uma gota de sangue para explorar". Como "proteção" contra a serpente de seus martírios, os trabalhadores têm de reunir suas cabeças e como classe conquistar uma lei estatal, uma barreira social intransponível, que os impeça a si mesmos de venderem a si e à sua descendência, por meio de contrato voluntário com o capital, à noite e à escravidão! No lugar do pomposo catálogo dos "direitos inalienáveis do homem" entra a modesta Magna Charta [...] (MARX, 1996a, p. 414). 
A resistência à imposição sem freios dos imperativos do capital é parte constitutiva do processo de produção. Assim, o trabalhador transforma-se em meio ao processo de trabalho, primeiramente devido ao processo de transformação da própria natureza externa ${ }^{11}$, porém, também, em meio à luta por melhores condições de trabalho. O vínculo contratual media a venda da força de trabalho, em que o indivíduo aparece como um mero portador de mercadorias: para isso, é necessário que se tenha o trabalhador livre ao mesmo tempo em que, no processo mesmo de produção há a possibilidade de, depois de concluído o negócio, note-se que nunca se foi nenhum agente livre. A ilusão do agente livre é bastante presente no Direito, certamente (PACHUKANIS, 2017). No entanto, em meio à própria luta dos trabalhadores, segundo Marx (2012b, 2013), seria possível (embora, claro, não necessário ao próprio processo) superar a mencionada ilusão jurídica.

Aqui, percebe-se: por meio do próprio processo produtivo da sociedade capitalista existe a possibilidade de, em meio à luta por melhores condições de trabalho, rumar-se para além desta ilusão jurídica. Trata-se de um momento em que se pode perceber que se foi obrigado a vender voluntariamente a força de trabalho, de modo a ser necessário resistir de um modo distinto: politicamente, como classe. Da conquista da concessão de direitos, tem-se a reunião de suas cabeças, a qual pode colocar-se contra o próprio contrato voluntário com o capital. Neste ponto, portanto, para Marx (2013), tem-se a possibilidade de uma passagem importante: da atomização da sociedade burguesa à organização como classe. E o modo pelo qual esta organização se dá, de início, passa pela cidadania - e, assim, em meio aos meandros da política (CHASIN, 2009) - e pelo terreno do Direito, ou seja, por campos tipicamente ligados à burguesia. Marx (2012b) destaca algo essencial: não é porque a luta dos trabalhadores passa necessariamente por campos que não são aqueles mais propícios a seus interesses (como o do Direito) que ela fica adstrita e estes campos.

A questão é bastante importante para o que tratamos, já que mostra ser possível uma passagem da resistência ao capital à formação - ainda que basilar - da consciência de classe, elemento essencial, segundo Marx (2013), para que se possa passar ao terreno revolucionário.

Diante do instrumento jurídico contratual, por meio do qual voluntariamente vendem sua força de trabalho e sua descendência, os trabalhadores organizam-se como classe e conquistam uma barreira social intransponível que é elevada ao estatuto de lei estatal em meio ao processo de guerra civil. Mostra-se, assim, que a luta política dos trabalhadores - que ultrapassa em muito o terreno do Direito - tem um grande ganho: o incremento da consciência de classe. No entanto, neste processo, conquistam-se concessões dentro do próprio terreno jurídico e a regulamentação fabril passa a se colocar efetivamente como algo próximo do que entendemos por Direito do trabalho. Este último é o resultado das lutas da classe trabalhadora, lutas estas que trazem conquistas imediatas ao trabalhador coletivo em meio à relação-capital. Trata-se de algo que tem por base a extração do mais-valor relativo. Ou seja, o caráter dúbio da questão aparece novamente: as limitações inerentes a este processo são visíveis; no entanto, também o são os ganhos. A partir deste ponto, ao se reconhecer enquanto classe social, e não só como um amontoado de indivíduos explorados, emergem possibilidades que se colocam para além do pomposo catálogo de direitos humanos.

Porém, de início, ficam claras igualmente as limitações de tal processo, que redundou na Magna Charta, e não na sublevação revolucionária dos trabalhadores diante do domínio do capital. Ou seja, em um momento inicial não haveria como a luta dos trabalhadores não se colocar, de um modo ou de outro, no terreno legal. Os ganhos possíveis em meio a estas conquistas de concessões poderiam, inclusive, ser substanciais em algum sentido. No entanto, o ganho real, de acordo com Marx $(2010,2013)$, poderia se explicitar somente ao passo que o Direito e a regulamentação jurídica passam a ser secundárias diante das possibilidades abertas no campo político: no limite, relacionado ao terreno revolucionário. As lutas cotidianas, bem como a resistência diante do capital, poderiam ter a importante função de trazer à tona a passagem do indivíduo atomizado à consciência de classe.

Trata-se do momento em que, ainda sob o terreno do Direito, a classe organiza-se e consegue conquistas, mesmo que modestas. Elas não seriam o essencial. Mas o processo pelo qual elas se constituem poderia ser revolucionário. Ao tratar do caso francês, Marx (2012a) traz um elemento bastante importante, que se relaciona a este aspecto dúbio das lutas sociais que passam pelo Direito:

Na primeira versão da Constituição, formulada pelas jornadas de junho, ainda constava o "droit au travail", o direito ao trabalho, a primeira fórmula desajeitada, que sintetizava as reivindicações revolucionárias do proletariado. Ela foi transformada no droit à l'assistance, no direito à assistência social, e qual é o Estado moderno que não alimenta de uma ou de outra forma os seus paupers [pobres]? Para o senso burguês, o direito ao trabalho é um contrassenso, um miserável desejo piedoso, mas por trás do direito ao trabalho está o poder sobre o capital, por trás do poder sobre o capital, a apropriação dos meios de produção, seu submetimento à classe operária associada, portanto, a supressão do trabalho assalariado, do capital e de sua relação de troca. Por trás do "direito ao trabalho" estava a Insurreição de Junho. A Assembleia Constituinte que declarou o proletariado revolucionário como de fato hors la loi, fora da lei, obrigou-se, 
com isso, por princípio, a expurgar da Constituição, da lei das leis, a fórmula por ele cunhada, ou seja, a anatematizar o "direito ao trabalho". Ela, porém, não se limitou a isso. Assim como Platão baniu de sua República os poetas, ela baniu da sua, por toda eternidade, o imposto progressivo. E o imposto progressivo não era só uma medida burguesa, aplicável dentro das relações de produção existentes a escalas maiores ou menores; ele também era o único meio de amarrar os estratos médios da sociedade burguesa à "honnête" república, reduzir a dívida pública, pôr em xeque a maioria antirrepublicana da burguesia. (MARX, 2012a, p. 76 , grifo do autor).

Novamente, vale destacar que Marx (2012a) trata na passagem de um caso específico, o francês. Deste modo, não há como transpor sem as devidas mediações as conclusões que o autor retira deste caso para outros países. No entanto, no que diz respeito a nosso tema é bastante significativo que Marx (2012a) trate da dubiedade da expressão direito ao trabalho. A primeira questão sobre o assunto é: o autor alemão não está tratando do que poderia ser chamado de Direito do trabalho (que viriam, parece-nos, a discutir sobre as condições de trabalho sob a relação-capital, bem como sobre a mercadoria força de trabalho). A fórmula seria certamente desajeitada; na forma da assistência social ela é muito mais palatável à burguesia e passa a ser somente um desejo piedoso. No entanto, e aqui está um ponto decisivo: por trás de tal fórmula desajeitada, que expressa certa transição incompleta do terreno do Direito ao terreno da revolução, estaria nada menos que “[...] a apropriação dos meios de produção, seu submetimento à classe operária associada [...]” (MARX, 2012a, p. 76). Ou seja, tratava-se daquilo que poderia suprimir o modo de produção capitalista, superando conjuntamente o próprio trabalho assalariado e, assim, o proletariado como classe. Marx (2012a) não defende o direito ao trabalho, portanto; antes, diz tratar-se de uma forma desajeitada de a classe trabalhadora se colocar diante do essencial. Trata-se do proletariado procurando colocar suas demandas em um terreno que não é o seu e, neste sentido - ou seja, já que o conteúdo de sua reivindicação ultrapassa o terreno do Direito tem-se maior possibilidade de transição do terreno do Direito ao terreno revolucionário. Se é verdade que os trabalhadores deveriam colocar-se em meio a este último, igualmente verdadeiro é que o direito ao trabalho precisou ser reduzido a uma fórmula piedosa de assistência social. Tratou-se de levar o direito ao trabalho inteiramente ao terreno do Direito, sem dubiedades.

\section{A decisiva redução da jornada de trabalho, portanto, só poderia se dar com a}

\section{transformação substantiva da}

produção, em que o processo

produtivo não é mais permeado

pela extração do mais-valor,

seja ele colocado em sua forma

absoluta ou em sua forma

relativa.

No campo político, no entanto, alternativas concretas estão colocadas. Diante de tal possibilidade, não só a burguesia francesa retira de campo o direito ao trabalho, mas também as medidas progressistas presentes na constituição ${ }^{12}$. Ou seja, no caso Francês, diante do impasse - caso se queira remeter ao que foi dito anteriormente, da antinomia colocada na própria realidade efetiva - a burguesia vai ao terreno contrarrevolucionário e, portanto, relega o terreno do Direito a um papel secundário. Se Marx (2010, p. 318) é claro ao dizer que "nosso terreno não é o terreno do direito, é o terreno revolucionário", não se trata tanto de ver até que ponto a "[...] formula desajeitada [...]" (MARX, 2012a, p. 76) do direito ao trabalho teria potencialidade de transitar do terreno do Direito ao revolucionário - Marx (2012a) é muito claro sobre a impossibilidade de se basear neste tipo de fórmula. Antes, trata-se de apontar, ao mesmo tempo, as limitações e os avanços que teriam sido trazidos da correlação entre o trabalhador coletivo, suas lutas e o emergente Direito do trabalho, corporificado da regulamentação fabril e na luta pela diminuição da jornada de trabalho. Uma questão parece ser decisiva: o momento em que Marx (2012a) vê maior potencialidades (mesmo que com inúmeras limitações) é aquele em que não se tem tanto a busca por uma regulamentação do trabalho assalariado, mas o momento, mesmo que desajeitado, em que se pode - embora isto não tenha ocorrido - passar do terreno do Direito ao revolucionário. A questão não é simples e envolve uma constatação: para o autor alemão (MARX, 2013), mesmo que em meio ao campo jurídico seja possível o desenvolvimento de uma consciência de classe, isto não basta. Seria necessário ir muito além do Direito do trabalho e ao trabalho. Ou seja, o proletariado reivindicaria o direito ao trabalho em um momento de organização desajeitada, sendo necessário explicitar conscientemente aquilo essencial à supressão da própria relação social capitalista. Ou seja, a importância das lutas que se colocam no terreno jurídico - bem como daquelas que se colocam no campo político (que não podemos tratar aqui) - está na possibilidade de, diante dos antagonismos classistas, 
ter-se uma passagem explícita e consciente ao terreno da revolução. A relação entre trabalho, luta de classes e Direito aparece trazendo à tona diversas limitações do terreno jurídico. Ao mesmo tempo, porém, traz a possibilidade de passagem deste terreno àquele que poderia - mediante uma luta política revolucionária superar o próprio capital.

\section{Conclusão: trabalho, fruto integral do trabalho e a necessidade de se colocar além do terreno do Direito}

No que toca o tema que aqui tratamos, parece ser claro que a capacidade de rumar para além do terreno do Direito é decisiva. Isso se dá, também, porque, em determinadas circunstâncias, em que a extração de maisvalor relativo tende a preponderar de modo bastante marcante, aparece a ilusão segundo a qual os ganhos conseguidos (conquistados) neste terreno poderiam ser um ponto de partida efetivo e progressivo para a derrocada do sistema capitalista de produção. Esta era claramente a crença de Ferdinand Lassalle, criticado por Marx (2012b) na Crítica ao Programa de Gotha. E o autor de O Capital é muito duro diante da demanda lassaliana por regulamentação, não só da jornada de trabalho, mas da distribuição justa dos frutos do trabalho, diz Marx (2012b, p. 28):

\footnotetext{
"Fruto do trabalho" é uma noção vazia, posta por Lassalle no lugar de conceitos econômicos determinados. O que é distribuição "justa"? Os burgueses não consideram que a atual distribuição é "justa"? E não é ela a única distribuição "justa" tendo como base o atual modo de produção? As relações econômicas são reguladas por conceitos jurídicos ou, ao contrário, são as relações jurídicas que derivam das relações econômicas? Os sectários socialistas não têm eles também as mais diferentes concepções de distribuição "justa"?
}

Marx (2012b) é muito duro na crítica à defesa do fruto integral do trabalho e da distribuição justa; ambas reivindicações deixariam de lado a crítica ao trabalho assalariado e, assim, ficariam, no limite, aquém da desajeitada e confusa fórmula do direito ao trabalho. Em verdade, Lassalle não teria conseguido colocar-se um milímetro além do terreno do Direito: seu socialismo estatizante buscaria uma regulamentação das relações de trabalho, criticando a “[...] lei de bronze dos salários [...]” (LÖWY, 2012, p. 13) e não a própria relação-capital (e o assalariamento). Para Marx (2012b), isto seria inaceitável. A fórmula lassalliana não seria só desajeitada; tratar-se-ia de uma fraseologia de uma noção vazia, que deixaria de lado o essencial. Neste sentido, "[...] no lugar de conceitos econômicos [...]" (MARX, 2012b, p. 28), há um palavrório sem sentido. Segundo Marx (2012a), seria necessário ser explícito; e se a fórmula do direito ao trabalho é confusa, ela trouxe em determinado momento alguma potencialidade. Já a defesa do fruto integral do trabalho seria vã, e a todo o momento suporia o assalariamento e, portanto, a relação-capital.

Para o que nos diz respeito aqui, vale destacar a base desta fraseologia: a inversão entre o jurídico e o econômico. O terreno que, na melhor das hipóteses, poderia surgir como um dos focos (e não o foco) de resistência é tomado por Lassalle - e também por autores como Proudhon, embora não possamos tratar aqui da questão - como se pudesse se colocar para além de sua determinação real e efetiva, calcada na ordem do capital. Marx (2012b) condena até mesmo a fraseologia da justiça, que aparece como típica de sectários socialistas, e não em meio à adequada apreensão da realidade ${ }^{13}$.

No que surge uma questão importante, dependente de algumas ponderações: o autor de $O$ Capital parte certamente da conformação da sociedade capitalista e da posição (Standpunkt) da classe trabalhadora neste sistema. Marx (2013) enxerga também como a luta por melhores condições de trabalho, como uma forma de resistência aos imperativos do capital, permanece em meio à sociabilidade deste. E isso se dá mesmo que possa trazer ganhos no que toca a consciência de classe. Nota-se também que haveria uma necessidade urgente de se transitar do terreno do Direito ao terreno revolucionário. A questão que se coloca, portanto, é a seguinte: até que ponto o apego ao ponto de vista do trabalho - e do que poderíamos chamar de Direito do trabalho - é resolutivo?

Isto não é de fácil resposta. No entanto, pelo que vimos, há de se notar que o modo como se apresenta o trabalho, na sociedade capitalista, depende do capital, e, portanto, supõe a relação-capital e o assalariamento. A perspectiva que se apresenta de início à classe trabalhadora leva a certa resistência diante da imposição da classe dos capitalistas. Isto, porém, é bastante dúbio, de modo que não necessariamente se tem a superação do terreno jurídico, que supõe o intercâmbio de mercadorias (e, portanto, o capital). A demanda pelo fruto integral do trabalho, bem como por uma distribuição justa, coloca-se, assim, com inúmeras limitações. Em verdade, tais reivindicações não conseguem ultrapassar a mera resistência do trabalho ao capital, o que leva a 
consequências bastante graves: o próprio sistema capitalista vem a ser tomado como eterno, no final das contas. A fórmula do direito ao trabalho, por mais que tenha por trás de si a possibilidade de remeter ao essencial, também vem a expressar, em verdade, certa confusão e certo caráter desajeitado da crítica à sociabilidade capitalista. Ou seja, mesmo no caso que em Marx (2012a, 2013) é mais elogioso, tem-se de modo claro o destaque das limitações quando se trata da relação entre trabalho, luta de classes e Direito. Isso tem um significado duplo: de um lado, não haveria como não se colocar nestas lutas cotidianas. Doutro lado, seria preciso, a partir delas, remeter para além do próprio campo jurídico, o que demandaria uma tematização sobre a política, e sobre os limites desta (CHASIN, 2009). Ou seja, o real debate sobre a obra de Marx passa pela questão do Direito, certamente. Mas remete à política e ao modo pelo qual esta se coloca na sociedade capitalista. E, claro, todas estas questões têm por base real o desenvolvimento socioeconômico.

Ater-se ao terreno do Direito, buscando um Direito do trabalho combativo e de resistência que progredisse, no limite, até uma espécie estatal de socialismo seria extremamente enganoso. Mesmo a fórmula desajeitada do direito ao trabalho seria melhor que isso, pois envolveria o modo confuso pelo qual se deu a luta de classes no solo francês em determinado momento. Com tal fórmula, tem-se por trás de uma reivindicação confusa, a classe operária associada e, portanto, a supressão do trabalho assalariado. Ou seja, o real conteúdo do direito ao trabalho estaria na supressão do capitalismo; no entanto, e isto é o essencial, diante de tal fórmula oscilante, não é tanto o proletariado que consegue tomar a dianteira do processo revolucionário francês, mas a burguesia que se coloca no terreno da revolução, mais precisamente, da contrarrevolução.

Ou seja, se os trabalhadores não se colocam para além do terreno jurídico de modo decidido, a burguesia toma as rédeas e afirma-se politicamente. A fórmula direito ao trabalho, portanto, traz consigo certa confusão que, ao fim, mesmo que tensione com a relação-capital, não traz à consciência a compreensão da real conformação da sociedade capitalista e, portanto, da necessidade de suprimi-la de modo decidido. A crítica marxiana ao Direito é clara e nela está contida uma crítica às limitações da perspectiva do trabalho que se coloca, de modo a trazer somente uma resistência, como polo antagônico ao capital; ou seja, para o autor, embora isto seja essencial a se conseguir, não basta o desenvolvimento de certa consciência de classe dos trabalhadores organizados.

É necessária a perspectiva que busque a supressão da relação-capital e, com ela, do próprio assalariamento. Ou seja, tem-se uma crítica à sociedade burguesa e ao assalariamento e, portanto, à própria existência das classes sociais. Pelo que se vê, tal crítica implica, também, em uma tomada de consciência sobre as limitações do terreno do Direito, e mesmo daquele terreno jurídico que remete ao direito ao trabalho, e não do trabalho. Trata-se da necessidade da passagem do terreno do Direito ao terreno da revolução. No que, por fim, é preciso ir um pouco mais longe: qual a relação desta temática com diversos debates marxistas sobre o trabalho? Para responder tal questão, vale a pena citar uma passagem da Crítica ao Programa de Gotha (MARX, 2012b). Ao tratar de um Direito que, em meio à transição comunista, volte-se à produção e tenha como medida o trabalho, diz Marx (2012b, p. 32, grifo do autor):

O direito dos produtores é proporcional a seus fornecimentos de trabalho; a igualdade consiste, aqui, em medir de acordo com um padrão igual de medida: o trabalho. Mas um trabalhador supera o outro física ou mentalmente e fornece, portanto, mais trabalho no mesmo tempo ou pode trabalhar por mais tempo; e o trabalho, para servir de medida, ou tem de ser determinado de acordo com sua extensão ou sua intensidade, ou deixa de ser padrão de medida. Esse igual direito é direito desigual para trabalho desigual. [...] Segundo seu conteúdo, portanto, ele é, como todo direito, um direito da desigualdade. O direito, por sua natureza, só pode consistir na aplicação de um padrão igual de medida; mas os indivíduos desiguais (e eles não seriam indivíduos diferentes se não fossem desiguais) só podem ser medidos segundo um padrão igual de medida quando observados do mesmo ponto de vista, quando tomados apenas por um aspecto determinado, por exemplo, quando, no caso em questão, são considerados apenas como trabalhadores e neles não se vê nada além disso, todos os outros aspectos são desconsiderados.

Marx (2012b, p. 33) trata das limitações burguesas, mais precisamente do “[...] estreito horizonte jurídico burguês [...]" que ainda se manifesta na transição à sociedade comunista. As limitações do terreno jurídico aparecem também no autor ao passo que elas deveriam ser superadas em meio ao processo de supressão das classes sociais. O Direito consiste sempre "[...] na aplicação de um igual padrão de medida [...]" (MARX, 2012b, p. 32), de modo que as individualidades multifacetadas das pessoas aparecem subsumidas a um de seus aspectos: os indivíduos são considerados somente como trabalhadores. Ou seja, as limitações deste terreno, na transição, aparecem como as limitações da perspectiva do trabalho e da produção material, que, sempre, é reino da necessidade ${ }^{14}$. Para Marx (2013), trata-se de se libertar do modo pelo qual a produção material se impõe cotidianamente à vida dos indivíduos, de modo que o trabalho deixe de se impor como um mero meio de 
vida, que subordina os outros aspectos da sociabilidade e da individualidade humana. Se superar a produção material e o trabalho concreto nunca é possível (MARX, 1996a), trata-se de buscar "[...] o verdadeiro reino da liberdade, mas que só pode florescer sobre aquele reino da necessidade como sua base. A redução da jornada de trabalho é a condição fundamental". (MARX, 1986b, p. 273). Ou seja, de um lado, é essencial a transformação do processo material de produção para que "[...] o homem social, os produtores associados, regulem racionalmente esse seu metabolismo com a Natureza, trazendo-o para seu controle comunitário, em vez de serem dominados por ele como se fora por uma força cega [...]" (MARX, 1986b, p. 273). Doutro lado, sempre é importante perceber que a produção material se coloca como o reino da necessidade, cuja influência direta na vida cotidiana deveria ser reduzida radicalmente. Ou seja, na superação decisiva do terreno do Direito, suprime-se o trabalho assalariado e, com isto, em meio ao controle comunitário, planejado e racional da produção tem-se as individualidades multifacetadas que se colocam como tais, e não como a expressão da subordinação brutal e diuturna dos homens ao processo produtivo. Tal redução da jornada do trabalho não se dá pela regulamentação jurídica, mas pela mudança substancial na própria produção. Como diz Marx (2012b, p. 33):

\begin{abstract}
Numa fase superior da sociedade comunista, quando tiver sido eliminada a subordinação escravizadora dos indivíduos à divisão do trabalho e, com ela, a oposição entre trabalho intelectual e manual; quando o trabalho tiver deixado de ser mero meio de vida e tiver se tornado a primeira necessidade vital; quando, juntamente com o desenvolvimento multifacetado dos indivíduos, suas forças produtivas também tiverem crescido e todas as fontes da riqueza coletiva jorrarem em abundância, apenas então o estreito horizonte jurídico burguês poderá ser plenamente superado e a sociedade poderá escrever em sua bandeira: "De cada um segundo suas capacidades, a cada um segundo suas necessidades!”
\end{abstract}

Se a posição do trabalho é elo essencial para a revolução das condições de produção burguesas, isto se dá porque a classe trabalhadora traz consigo a possibilidade de supressão das próprias classes sociais, e portanto, também de si mesma. Para Marx (2013), este processo não é simples, claro; no entanto, passa por uma crítica decisiva ao terreno do Direito e às ilusões e confusões que advém das lutas que se atém a este. Mesmo que o trabalho apareça - em uma transição - como medida do Direito, isto não resolve a questão: em verdade, em meio à relação imbricada entre reino da necessidade e da liberdade, seria preciso buscar a fase superior da sociedade comunista, em que o trabalho deixa de ser mero meio de vida e se torna a primeira necessidade vital.

Esta última é a base do reino da liberdade, mas ela deixa de se impor tal qual nas sociedades classistas - marcadas pela escassez socialmente construída. Tendo-se em conta que, para os comunistas, "a redução da jornada de trabalho é a condição fundamental" (MARX, 1986b, p. 273) para o gozo da liberdade dos indivíduos multifacetados, há de se colocar que Marx explicitamente é um crítico do Direito (mesmo do que podemos chamar de Direito do trabalho e ao trabalho) e não se coloca como alguém que toma a perspectiva do trabalho de modo acrítico. Antes, trata-se de tomá-la pelo que é, um elo intermediário na supressão das classes sociais, do trabalho assalariado, do Estado, do Direito e de todas as determinações reflexivas que acompanham o capitalismo. Longe de procurar assegurar o direito ao fruto integral do trabalho e à distribuição justa da produção dos assalariados, o autor de $O$ Capital traz os meandros de uma crítica ao capital e, de modo reflexo, ao trabalho subordinado ao capital. A decisiva redução da jornada de trabalho, portanto, só poderia se dar com a transformação substantiva da produção, em que o processo produtivo não é mais permeado pela extração do mais-valor, seja ele colocado em sua forma absoluta ou em sua forma relativa.

O trabalho é central na vida dos indivíduos na sociedade capitalista, fazendo com que estes coloquem-se socialmente somente como trabalhadores. Assim, a própria revolta diante do domínio do capital (e, portanto, da existência do assalariamento) é que poderia levar à supressão da "[...] pré-história da sociedade humana". (MARX, 2008, p. 48). Mas a questão é bastante meandrada, já que tal revolta aparece cotidianamente como uma mera resistência, em que, por vezes, o papel ativo da regulamentação jurídica do trabalho tem um papel importante. Trata-se, segundo Marx (2010), em verdade, de ir de encontro ao terreno do Direito e de colocarse no terreno da revolução.

Pelo que vimos, tal revolta e tal resistência não estão adstritas necessariamente a certa retroalimentação do sistema capitalista, como parece sugerir Edelmam (2016). Passar de certa atomização à consciência de classe não é pouco. No entanto, em Marx, a perspectiva da classe trabalhadora, em sua imediatidade, é muito mais problemática do que pode ter parecido em certa leitura apressada da obra marxiana. Trata-se de enxergar que a classe trabalhadora é vista pelo autor como portadora de diversas potencialidades, possibilidades estas irrealizáveis em qualquer uso instrumental do que podemos chamar de Direito do trabalho. Dizem Marx e Engels (2007, p. 66) sobre a relação entre a classe social, o trabalho subsumido ao capital, o Estado, e poderíamos dizer, o Direito: “[...] os proletários, para afirmar a si mesmos como pessoas, têm de 
suprassumir [aufheben] sua própria condição de existência anterior, que é, ao mesmo tempo, a condição de toda a sociedade anterior, isto é, o trabalho ${ }^{15}$. Eles também se encontram, por isso, em oposição ao Estado, a forma pela qual os indivíduos se deram, até então, uma expressão coletiva, e têm de derrubar o Estado para impor a sua personalidade". Ou seja, trata-se da necessidade de superação das classes sociais mesmas, do Estado, do Direito. Somente assim seria possível aos indivíduos imporem sua personalidade, sua individualidade multifacetada. Para que isso se desse, no entanto, seria mais que necessário, em meio às lutas concretas, passar do terreno do Direito para o revolucionário.

A luta de classes colocada no campo jurídico (mesmo aquele relacionado à perspectiva do trabalho), ao mesmo tempo em que se conforma como uma resistência dúbia, que busca conquistar concessões, precisa remeter para além do Direito mesmo. Isso só pode ser feito, em um primeiro momento, cotidianamente. E, por mais difícil que seja, segundo Marx (2013), isto é extremamente necessário caso se deseje uma crítica efetiva às misérias inerentes ao modo de produção capitalista. Da relação entre trabalho, luta de classes e Direito, tem-se, ao mesmo tempo, a necessidade de resistência e de lutas de um lado, e, doutro, a limitação do terreno do Direito. Tratar-se-ia se passar deste terreno, que se apresenta no cotidiano da classe trabalhadora, ao questionamento substancial do próprio sistema de assalariamento, da relação-capital e, assim, do modo de produção capitalista.

\section{Referências}

ANTUNES, R. Os sentidos do trabalho. São Paulo: Boitempo, 2008.

CHASIN, J. Marx: estatuto ontológico e resolução metodológica. São Paulo: Boitempo, 2009.

ENGELS, F. Prefácio da edição inglesa. In: MARX, K. O capital: crítica da economia política: o processo de produção do capital. São Paulo: Nova Cultural, 1996. v. 1, t. 1, p. 151-154. (Os Economistas).

ENGELS, F.; KAUTSKY, K. O socialismo jurídico. 2. ed. rev. São Paulo: Boitempo, 2012.

EDELMAN, B. A legalização da classe operária. São Paulo: Boitempo, 2016.

LÖWY, M. Prefácio à edição brasileira. In: MARX, K. Crítica do programa de Gotha. São Paulo: Boitempo, 2012. p. 13-17.

MÁRKUS, G. Marxismo e antropologia: o conceito de "essência humana" na filosofia de Marx. São Paulo: Expressão Popular: EDIUNESC, 2015.

MARX, K. As lutas de classes na França. São Paulo: Boitempo, 2012a.

MARX, K. Contribuição à crítica da economia política. 2. ed. São Paulo: Expressão Popular, 2008.

MARX, K. Crítica do programa de Gotha. São Paulo: Boitempo, 2012b.

MARX, K. Miséria da filosofia. São Paulo: Ícone, 2004.

MARX, K. Nova Gazeta Renana. São Paulo: Educ, 2010.

MARX, K. O 18 de brumário de Luís Bonaparte. São Paulo: Boitempo, 2011.

MARX, K. O capital: crítica da economia política: livro I: o processo de produção do capital. São Paulo: Boitempo, 2013.

MARX, K. O capital: crítica da economia política: livro III: o processo global da produção capitalista. São Paulo: Boitempo, 2017.

MARX, K. O capital: crítica da economia política: o processo de produção do capital. São Paulo: Nova Cultural, 1996a. v. 1, t. 1. (Os Economistas).

MARX, K. O capital: crítica da economia política: o processo de produção do capital. São Paulo: Nova Cultural, 1996b. v. 1, t. 2. (Os Economistas).

MARX, K. O capital: crítica da economia política: o processo global da produção capitalista. 2. ed. São Paulo: Nova Cultural, $1986 a$. v. 3, t. 1. (Os Economistas).

MARX, K. O capital: crítica da economia política: o processo global da produção capitalista. 2. ed. São Paulo: Nova Cultural, $1986 b$. v. 3, t. 2. (Os Economistas).

MARX, K.; ENGELS, F. A ideologia alemã. São Paulo: Boitempo, 2007.

MELOSSI, D; PAVARINI, M. Cárcere e fábrica: as origens do sistema penitenciários (séculos XVI-XIX). Rio de Janeiro: Instituto Carioca de Criminologia: Revan, 2006.

PACHUKANIS, E. Teoria geral do direito e marxismo. São Paulo: Boitempo, 2017.

POSTONE, M. Tempo, trabalho e dominação social: uma reinterpretação da teoria crítica de Marx. São Paulo: Boitempo, 2014.

RUSCHE, G.; KIRCHHEIMER, O. Punição e estrutura social. 2. ed. Rio de Janeiro: Instituto Carioca de Criminologia: Revan, 2004.

SARTORI, V. B. Apontamentos sobre justiça em Marx. Nomos, Fortaleza, v. 37, n. 1, p. 321-353, jan./jun. 2017.

SARTORI, V. B. Direito, política e reconhecimento: apontamentos sobre Karl Marx e a crítica ao Direito. Revista da Faculdade de Direito - UFPR, Curitiba, v. 61, n. 2, p. 203-233, maio/ago. 2016.

SARTORI, V. B. Lukács e a crítica ontológica ao direito. São Paulo: Cortez, 2010.

SARTORI, V. B. Trabalho, riqueza e natureza humana: Marx e a crítica ao modo de produção capitalista. Sapere aude, Belo Horizonte, v. 9, n. 18, p. 78-103, jul./dez. 2018. 


\section{Notas}

1 Como diz Chasin (2009, p. 25-26, grifo do autor): "tal análise, na melhor da tradição reflexiva, encara o texto - a formação ideal - em sua consistência autossignificativa, aí compreendida toda a grade de vetores que o conformam, tanto positivos como negativos: o conjunto de suas afirmações, conexões e suficiências, como as eventuais lacunas e incongruências que o perfaçam. Configuração esta que em si é autônoma em relação aos modos pelos quais é encarada, de frente ou por vieses, iluminada ou obscurecida no movimento de produção do para nós que é elaborado pelo investigador, já que, no extremo e por absurdo, mesmo se todo o observador fosse incapaz de entender o sentido das coisas e dos textos, os nexos ou significados destes não deixariam, por isso, de existir [...]".

2 Deve-se ressaltar que, como a própria experiência do século XX mostra, mesmo este tipo de questionamento nem sempre é suficiente para a supressão (Aufhebung) do capital, sendo necessária a confluência de diversos fatores em meio às lutas sociais anticapitalistas. Aqui, porém, não poderemos tratar deste importante assunto.

3 Note-se que esta última citação de Marx traz à tona o caráter objetivo da aparência colocada sob a égide do capital.

4 Aqui, não poderemos trazer nenhuma conceituação sobre o que seria efetivamente o Direito do trabalho. Estamos conscientes que ele ultrapassa a regulamentação da atividade fabril, tratada por Marx (2013). No entanto, acreditamos que a relação deste ramo do Direito com a emergência da questão social e do pauperismo decorrente da implementação da grande indústria é suficiente para que seja válido trazer a correlação de Marx (2012b, 2013) com o tema.

5 Diz Marx (2013, p. 485) sobre o mais-valor relativo e o mais-valor absoluto, explicitando a diferença entre ambos: "o mais-valor obtido pelo prolongamento da jornada de trabalho chamo de mais-valor absoluto; o mais-valor que, ao contrário, deriva da redução do tempo de trabalho necessário e da correspondente alteração na proporção entre as duas partes da jornada de trabalho chamo de mais-valor relativo".

$6 \operatorname{DizMarx}(2013$, p. 961): "trabalhadores livres no duplo sentido de que nem integram diretamente os meios de produção, como os escravos, servos etc., nem lhes pertencem os meios de produção, como no caso, por exemplo, do camponês que trabalha por sua própria conta etc., mas estão, antes, livres e desvinculados desses meios de produção".

7 Como diz Marx (1996a, p. 293): “a esfera da circulação ou do intercâmbio de mercadorias, dentro de cujos limites se movimentam compra e venda de força de trabalho, era de fato um verdadeiro éden dos direitos naturais do homem. O que aqui reina é unicamente Liberdade, Igualdade, Propriedade e Bentham. Liberdade! Pois comprador e vendedor de uma mercadoria, por exemplo, da força de trabalho, são determinados apenas por sua livre-vontade. Contratam como pessoas livres, juridicamente iguais. O contrato é o resultado final, no qual suas vontades se dão uma expressão jurídica em comum. Igualdade! Pois eles se relacionam um com o outro apenas como possuidores de mercadorias e trocam equivalente por equivalente. Propriedade! Pois cada um dispõe apenas sobre o seu. Bentham! Pois cada um dos dois só cuida de si mesmo. Oúnico poder que os junta e leva a um relacionamento é o proveito próprio, a vantagem particular, os seus interesses privados. Ejustamente porque cada um só cuida de si enenhum do outro, realizam todos, em decorrência de uma harmonia preestabelecida das coisas ou sob os auspícios de uma previdência toda esperta, tão somente a obra de sua vantagem mútua, do bem comum, do interesse geral”.

8 Aqui, infelizmente, não poderemos tratar dos meandros desta questão, que são muitos.

9 É importante destacar que Marx nunca traz seus posicionamentos em abstrato, sempre remetendo a questões concretas, ligadas a modos específicos pelos quais o capitalismo se coloca em cada país. Sobre o assunto, é interessante destacar que, segundo Engels (1996, p. 63), o próprio Marx teria admitido em algum momento, e reconhecendo a pequena chance e o caráter de exceção, uma passagem legal e pacífica ao socialismo: “[...] ao menos na Europa, a Inglaterra é o único país onde a inevitável revolução social poderia realizar-se inteiramente por meios pacíficos e legais. Certamente ele nunca se esqueceu de acrescentar que não esperava que as classes dominantes da Inglaterra se submetessem a essa revolução pacífica e legal sem tentar uma proslavery rebellion".

10 Sobre a importância da diferença entre política e Direito em Marx ver Sartori (2016).

11 Diz Marx (1996a, p. 297): "ao atuar, por meio desse movimento, sobre a Natureza externa a ele e ao modificá-la, ele modifica, ao mesmo tempo, sua própria natureza".

12 Aponta Marx (2011,p. 80, grifo do autor) sobre a França: "quer se tratasse do direito de petição ou do imposto do vinho, da liberdade de imprensa ou do livre-comércio, de clubes ou da lei orgânica municipal, da proteção da liberdade pessoal ou da regulamentação do orçamento do Estado, a senha sempre se repete, o tema permanece sempre o mesmo, a sentença sempre já está pronta e tem o seguinte teor imutável: "socialismo!". Declara-se como socialista o liberalismo burguês, o Iluminismo burguês e até a reforma financeira burguesa. Era considerado um ato socialista construir uma ferrovia onde já havia um canal, e era um ato socialista defender-se com um bastão ao ser atacado com uma espada".

13 Para um tratamento da questão da justiça em Marx ver Sartori (2017).

14 Em O Capital, diz Marx (1986b, p. 273): "a riqueza real da sociedade e a possibilidade de constante expansão de seu processo de produção não depende, portanto, da duração do mais-trabalho, mas de sua produtividade e das condições mais ou menos ricas de produção em que ela transcorre. O reino da liberdade só começa, de fato, onde cessa o trabalho determinado pela necessidade e pela adequação a finalidades externas; portanto, pela própria natureza da questão, isso transcende a esfera da produção material propriamente dita. Assim como o selvagem tem de lutar com a Natureza para satisfazer suas necessidades, para manter e reproduzir sua vida, assim também o civilizado tem de fazê-lo, e tem de fazê-lo em todas as formas de sociedade e sob todos os modos de produção possíveis. Com seu desenvolvimento, amplia-se esse reino da necessidade natural, pois se ampliam as necessidades; mas, ao mesmo tempo, ampliam-se as forças produtivas, que as satisfazem". Para uma análise cuidadosa da passagem ver Sartori (2018).

15 Aqui se trata do trabalho subsumido ao capital, e não do trabalho colocado como metabolismo com a natureza. 


\section{Vitor Sartori}

vitorbsartori@gmail.com

Doutorado em Filosofia e Teoria Geral do Direito pela Universidade de São Paulo (USP)

Professor adjunto da Faculdade de Direito da Universidade Federal de Minas Gerais (UFMG)

\section{UFMG}

Av. João Pinheiro, 100 - Centro

Belo Horizonte - Minas Gerais - Brasil

CEP: $30.130-180$

\section{Agradecimentos \\ Agradeço a Elcemir Paço Cunha, Ronaldo Vielmi Fortes, Claudinei Cássio, David Gomes e Gustavo Seferian pelo debate que possi-} bilitou a escrita deste artigo.

Agência financiadora

Não se aplica.

Contribuições dos autores

Não se aplica.

\author{
Aprovação por Comitê de Ética e consentimento para parti- \\ cipação \\ Não se aplica.

\section{Consentimento para publicação} \\ Não se aplica. \\ Conflito de interesses \\ Não há conflito de interesses.
}

